\title{
New Approaches to Providing of Environmental Management in Ukraine on the Way to Euro Integration
}

\author{
Olena Gulac ${ }^{1}$, Valentyna Goshovska², Volodymyr Goshovskyi ${ }^{3}$ and Liudmyla \\ Dubchak $^{4}$
}

\begin{abstract}
The article is devoted to the research of the latest approaches to providing of environmental management in Ukraine on the way to European integration. Based on the research, the necessity of introducing new approaches to providing of environmental management in Ukraine as one of the most important directions of European integration processes in Ukraine as a whole has been substantiated. The ways of improvement of separate directions of ecological management are offered, which are considered in the article through the prism of separate functions of ecological management and are considered innovative, in particular, for Ukraine. The European aspirations of Ukraine in the environmental sphere have been argued by the norms of the recently adopted Association Agreement between Ukraine, on the one hand, and the European Union, the European Atomic Energy Community and their member states, on the other. The prospective directions of introduction of the mentioned approaches in the modern practice of public administration of Ukraine, given the high environmental risks and threats faced by the entire world community, are indicated.
\end{abstract}

Keywords: environmental management, public management of the environmental sphere, new approaches to providing of environmental management, eurointegration, European integration processes in the environmental sphere.

\section{Introduction}

Nowadays, in Ukraine, there is an urgent need for significant transformational changes in the system of public management in general, as well as in certain branches and spheres of social life. This process is particularly relevant, given the rapid European integration progress that is being made by our state today. One of the most important areas that needs relevant substantive organizational and legal changes is environmental sphere. However, the nature of the relevant activity in it indicates significant problems. These include the lack of a clear mechanism for differentiating powers by government levels in the field of environmental relations and nature use relationships, efficiency (its

${ }^{1} \mathrm{PhD}$., Associate Professor of the Department of Administrative and Financial Law of the National University of Life and Environmental Sciences of Ukraine.

${ }^{2}$ Dr., prof., Director of the Institute for Advanced Training of Management Personnel, Head of the Department of Parliamentarism and Political Management of the Department of parliamentarism and political management Academy for Public Administration under The President of Ukraine.

${ }^{3}$ Dr., Professor of the Department of Administrative and Criminal Law of Oles Honchar Dnipro National University.

${ }^{4} \mathrm{PhD}$., associate professor, associate professor of the Department of parliamentarism and political management Academy for Public Administration under The President of Ukraine. 
criteria) for the construction and organization of the system of environmental management bodies (its structure and competence), priority directions in the construction of such a system, the forms and methods of implementation of certain functions of environmental management, etc.

A number of scientific publications of domestic and foreign scientists are devoted to issues related to the study of the issues of environmental management in Ukraine on the road to European integration and its components. Their work focuses attention on various aspects and manifestations of the above mentioned issues. In the context of the themes raised by us, deserve attention, among other things, the scientific works of: V. Averyanov, V. Andreytsev, A. Hetman, V. Loozo, I. Girenko, I. Zhochkina, Y. Krasnova, M. Krasnova, G. Balyuk, A. Bobkova, A. Lobanov, O. Demenko, V. Ladychenko, L. Golovko, I. Shevchenko, which cover issues that are more or less tangent to the problems identified by the authors.

At the same time, it should be noted that despite the long scientific discourse and important applied developments around the issue raised, the theoretical and practical principles of the formation and implementation of the new approaches to providing of environmental management in Ukraine in the context of Ukraine's European integration aspirations in the scientific literature are to a certain extent explained in a fragmentary way, without exercise of complex and systematic analysis and taking into account legal novels.

The lack of comprehensive scientific developments, taking into account the current organizational and legal changes, new reforms in the field of research, within our country and not only, causes the urgent need for further scientific and applied research in this direction.

The purpose of this article is to study the issues related to the substantiation of the need to introduce new approaches to providing environmental management in Ukraine as one of the most important directions of the European integration processes of our country; identification and analysis of the main areas of such activity, including through the relevant obligations of our state, fixed by international agreements.

\section{Directions of Improvement of Ecological Management}

The main content of public management is the organizing influence of the carriers of state and government powers on social relations and processes in order to streamline, coordinate and direct them through various types of normative and regulatory actions to enforce laws and other legal acts of the state ${ }^{1 ; 2}$.

Under ensuring of European integration processes are understood as a complex

1 Averyanov, V.B. (2004). Shche raz pro zmist i spivvidnoshennia poniat «derzhavne upravlinnia» $\mathrm{i}$ «vykonavcha vlada»: problemni notatky [Once more about the content and correlation of the concepts of "state administration" and "executive power": problem notes]. Pravo Ukrainy - The law of Ukraine, 5, 113115 [in Ukrainian], p. 114.

2 Svitlychny, O. P. (2011). Shchodo spivvidnoshennia poniat «derzhavne upravlinnia» i «publichna administratsiia» [The relation between the concepts of "state administration" and "public administration"]. Naukovyi visnyk Natsionalnoho universytetu bioresursiv i pryrodokorystuvannia Ukrainy: Seriia «Pravo» — Scientific Bulletin of the National University of Life and Environmental Sciences of Ukraine: Series "Law", 165-2,189-194 [in Ukrainian], p. 189-190. 
of legislative, institutional and organizational measures. Their implementation can be organized in the form of a state target program, strategy or by other tools.

The urgency of the environmental component among the priority principles of the European integration policy of our state is increasing and gaining qualitatively new dimensions in the sense that despite the scientific and technological progress and other indisputable achievements that humanity now actively uses, the world is now on the verge of an ecological catastrophe. Natural resources are not limitless. Thus, the relation of an individual to the environment is a litmus test of the relation of an individual nation or state to the planet Earth ${ }^{3}$.

Every next year, the world community recognizes the fact that the environment and its state are the basis of the economy, security, and, accordingly, affects on political decisions of a separate country, a separate region, and the entire planet ${ }^{4}$.

Ukraine's independence has led to its active inclusion in international integration processes through the implementation of the provisions of the concept of sustainable development, biodiversity, ecosystem approach and balanced use of natural resources. On the other hand, the signing by the state of a significant number of international agreements requires the improvement of the existing legislation in accordance with the requirements of the European Union ${ }^{5}$.

The task of forming new approaches to improving the administrative and legal framework of European integration processes is dictated not only by the objectives of the very environmental reform in Ukraine, but also by the processes of integration of the Ukrainian society into a single European space, bringing the standards of state and political activity to the standards common in the European community.

Practical activity in implementing the institutional and administrative potential of European integration is the direct introduction of European standards in all spheres of public life and the involvement of the broader public of Ukrainian society in this process. Unfortunately, so far, European landmarks of internal development have not become dominant in the socio-political life of our state. We are seeing the unrestrained desire of the Ukrainian political elite not so much to integrate into European structures as to acquire official membership (priority is given not to the content of the process, but to the form) ${ }^{6}$.

3 Gulak, O.V. (2016). Do pytannia zabezpechennia ekolohichnoi bezpeky v suchasnykh sotsialnoekonomichnykh umovakh [On the issue of ensuring environmental safety in modern socio-economic conditions]. Porivnialno-analitychne pravo - Comparative and analytical right,1, 182-185. Retrieved from http://www.pap.in.ua/1_2016/54.pdf [in Ukrainian], p. 182.

4 Shevchenko, I.V. (2013). Yevrointehratsiini vyklyky dlia ekolohichnoi polityky Ukrainy [European Integration Challenges for Ukraine's Environmental Policy]. Problemy ratsionalnoho vykorystannia sotsialno-ekonomichnoho ta pryrodno-resursnoho potentsialu rehionu: Intehratsiia ta innovatsiina transformatsiia - Problems of rational use of socio-economic and natural-resource potential of the region: Integration and innovation transformation, 4, 65-72 [in Ukrainian], p. 70.

5 Girenko, I.V. (2016). Pravova okhorona roslynnoho svitu Ukrainy [Legal protection of the plant world of Ukraine]. Extended abstract of Doctor's thesis. Kharkiv: Nat. lawyer acad. Ukraine to them Yaroslav the Wise [in Ukrainian], p. 1.

${ }^{6}$ Lobanov. A. A. Demenko, O. F. (2013). Yevropeiska intehratsiia Ukrainy: problemy ta perspektyvy realizatsii instytutsiinoho ta administratyvnoho potentsialu [European integration of Ukraine: problems and perspectives of institutional and administrative potential realization]. Visnyk Natsionalnoho universytetu oborony Ukrainy - Bulletin of the National Defense University of Ukraine, 5 (36), 354-357 [in Ukrainian]. P. 355. 
Nevertheless, extremely important importance is attached to convergence of environmental legal regulation with the aim of implementing the EU environmental policy, which is characterized by considerable positivism in solving environmental problems of regional, national and transboundary importance, and Ukraine, which directs its environmental policy in the context of transposition into provisions, directives, regulations of EU, the introduction of European principles of environmental legal regulation, consolidated with the experience of European countries and the adopted rules at the level of the Parliament of the EU, others authorized bodies of the EU ${ }^{7}$.

Therefore, will try to outline the directions of improvement of environmental management which we consider through the prism of separate functions of environmental management and consider innovative, in particular, for Ukraine.

\subsection{Environmental planning}

With regard to environmental planning it is expedient to talk about the establishment of the mandatory development, adoption and implementation in the established terms of the ecological plans and programs, based on the documents of the environmental certification of the territory and with the condition of the introduction of mechanisms of public-private partnership. The mechanisms of European integration, in turn, provide for a much wider involvement of the public in environmental planning, taking into account public opinion. Necessary at the level of domestic legislation is the development of a number of relevant institutes and norms of law that would provide wider rights and opportunities for civil society in this field of research.

\subsection{Environmental supervision}

Regarding environmental supervision, it is a question of establishing a clear separation of powers, orientation of supervision not only for detection and termination, but also for the prevention of environmental offenses. The task of environmental supervision, according to the logic of the relevant activity adopted in the European community, is not the application of sanctions to the relevant legal norms, but rather such a construction of a legal regulation mechanism that would allow achieving such a level of efficiency and organization of social relations in which sanctions would act role of "rifles on stage".

\subsection{Environmental monitoring}

A characteristic feature of the emerging pan-European system of environmental safety and the resolution of environmental problems is the attention to the development of an environmental monitoring system. In this regard, one of the most urgent areas of environmental reform in Ukraine is to clarify the objects of monitoring and legal forms of its implementation, both at the national level as a whole, and at the level of individual regions and communities. Important in the system of environmental monitoring is the

7 Andreytsev, V.I. (2016). Aktualni problemy konverhentsii ekolohichnoho zakonodavstva Ukrainy do zakonodavstva YeS [Actual Problems of Convergence of the Environmental Legislation of Ukraine to EU Legislation]. Aktualni problemy konverhentsii ekolohichnoho zakonodavstva Ukrainy do Zakonodavstva Yevropeiskoho Soiuzu - Actual Problems of Convergence of the Environmental Legislation of Ukraine to EU Legislation: Proceedings of All-Ukrainian Sciences. Round Table (p. 5). Dnipro [in Ukrainian], p. 5. 
establishment of its criteria, timely review of environmental norms and standards. In the national legislation of Ukraine it is necessary to consolidate the norm on the prevention of revision of environmental standards in the direction of their deterioration.

\subsection{Environmental expertise}

From the point of view of the European Community and its institutes, another important direction of environmental transformation in Ukraine is the transformation of the Institute of Environmental Expertise. In this direction it is expedient to talk about specification of a specific list of objects of regional environmental expertise, taking into account the specific ecological, social and economic conditions of the region ${ }^{8}$.

After analyzing the main directions of improvement of public administration in the context of providing European integration processes in the environmental sphere, it is worth saying that one of its main areas is the regional environmental expertise, because it should take into account the specifics of the region in which the expertise is conducted. Also, it should be recalled that the Law of Ukraine "On Environmental Expertise" has expired on the basis of the Law of Ukraine "On Environmental Impact Assessment".

\subsection{The system of environmental normalization}

The reform of the ecological standardization function serves as a direction for improving the management of European integration processes in the environmental sphere related to environmental monitoring. In Ukraine, this system was formed in Soviet times, based on the tasks of accelerated industrialization of the country by totalitarian methods, the implementation of which environmental norms, although recognized, but did not play any significant significance, besides, as all in the Soviet Union, they were exclusively planned character, that centrally was set. In this regard, it is necessary to talk about the introduction of such an approach that would determine the application of state regulation depending on the category of the object that has a negative impact on the environment, as well as taking measures to form an interest in using the best available technologies, taking into account the real state of the environment in the region ${ }^{9}$.

\section{Formation of a Regional System of Environmental Management Bodies}

Adequate accounting of the economic, ideological, socio-political, and ecological diversity of the regions of Ukraine will lead to the formation of a specific system of

8 Zhochkina, I.N. (2015). Rehyonalnoe hosudarstvennoe эkolohycheskoe upravlenye: kontseptsyia sovremennoho mekhanyzma pravovoho rehulyrovanyia [Regional state environmental management: the concept of the modern mechanism of legal regulation]. Doctor's thesis. Moscow: Moscow State University named after MV Lomonosov [in Russia], p. 195.

9 Zhochkina, I.N. (2015). Rehyonalnoe hosudarstvennoe эkolohycheskoe upravlenye: kontseptsyia sovremennoho mekhanyzma pravovoho rehulyrovanyia [Regional state environmental management: the concept of the modern mechanism of legal regulation]. Doctor's thesis. Moscow: Moscow State University named after MV Lomonosov [in Russia], p. 184. 
environmental management bodies in each of them. This system should be determined taking into account the factors specific to a particular region (see Table1).

The essential aspect of improving the management of European integration processes in the environmental sphere should be the creation of a variety of types of bodies of regional public environmental management in the identity of their functions, as well as expert, advisory and coordinating bodies created with them (public, environmental, scientific and technical councils, interdepartmental commissions), while preserving a single normative basis for them not only within Ukraine but also throughout the European Union ${ }^{10}$.

Table1: Definitive factors in the formation of the regional system of environmental management bodies

\begin{tabular}{|l|l|}
\hline Factors & Brief description (example) \\
\hline $\begin{array}{l}\text { Socio- } \\
\text { political }\end{array}$ & $\begin{array}{l}\text { The size and development of the territory of the region, its geopolitical situation, population } \\
\text { density, institutional and cultural characteristics. }\end{array}$ \\
\hline Ecological & $\begin{array}{l}\text { The natural and resource potential of the region, the area of the lands of the territories under } \\
\text { special protection, the number of deposits of basic minerals. }\end{array}$ \\
\hline Economic & $\begin{array}{l}\text { The level of socio-economic development of the region, the number of objects that have a } \\
\text { negative impact on the environment on the territory of a specific subject; the features of the } \\
\text { placement of productive forces, the level of anthropo- and man-made load. }\end{array}$ \\
\hline
\end{tabular}

In the course of the environmental reform carried out, namely, in improving the administrative and legal provision of European integration processes in the environmental sphere, it will inevitably touch on the issues of incompleteness of the division of powers between levels of executive power. This problem does not allow to establish the limits of proper and possible behavior in the behavior of subjects of regional state environmental management of different levels, as well as in the activities of legal entities and individuals and their associations.

\section{Public Participation in Solving Environmental Problems of the Country}

As stated above, the most important direction for improving the environmental management in Ukraine on the way to European integration is the promotion of participation of civil society and individual citizens both in solving environmental problems of the country and in environmental management as a whole. In the latter case we are talking about the participation of citizens and public associations in the implementation of regional public environmental management and understood as their participation in public environmental monitoring, public environmental expertise, in conducting a referendum on environmental issues ${ }^{11}$. It should also be said that

10 Zhochkina, I.N. (2015). Rehyonalnoe hosudarstvennoe эkolohycheskoe upravlenye: kontseptsyia sovremennoho mekhanyzma pravovoho rehulyrovanyia [Regional state environmental management: the concept of the modern mechanism of legal regulation]. Doctor's thesis. Moscow: Moscow State University named after MV Lomonosov [in Russia].

11 Zhochkina, I.N. (2015). Rehyonalnoe hosudarstvennoe эkolohycheskoe upravlenye: kontseptsyia sovremennoho mekhanyzma pravovoho rehulyrovanyia [Regional state environmental management: the concept of the modern mechanism of legal regulation]. Doctor's thesis. Moscow: Moscow State University named after MV Lomonosov [in Russia], p. 184. 
integration into European mechanisms includes the development of a legal mechanism for environmental education and environmental marketing, the creation of legal and institutional guarantees for media activities in the environmental sphere.

\section{Institute of Environmental Advice}

The objectives of European integration of Ukraine put forward new requirements for the nature of state and legal regulation of environmental relations in it. In accordance with the European methodologies of the results of public activities of the EU member states, public regulation in the environmental sphere must: be differentiated into ecological and industrial-ecological. At present, public regulation derives from an overly optimistic concept of "zero-impact", that is, it assumes that industry must produce goods without any environmental change, which is impossible, therefore, the task of legislation is not to prohibit influence, but to determine the level of this influence acceptable to society, based on a set of factors - technological, economic, social; administrative-legal regulation of ecological relations should provide balance of ecological, economic, social interests. However, we should note that for today there are no institutions for developing such a balance, so it is made "in the shade", causing corruption and distortion of data on the impact. Environmental advice in the areas and in communities can become like such institution ${ }^{12}$.

Table 2: Proposals for improvement of certain areas of environmental management in Ukraine

\begin{tabular}{|l|l|}
\hline $\begin{array}{l}\text { Directions of } \\
\text { environmental } \\
\text { management }\end{array}$ & The content of the proposal \\
\hline $\begin{array}{l}\text { Environmental } \\
\text { planning }\end{array}$ & $\begin{array}{l}\text { Maximum wide involvement of the public in environmental planning, consideration } \\
\text { of public opinion in its course and relevant changes in the system of national } \\
\text { legislation of Ukraine. }\end{array}$ \\
\hline $\begin{array}{l}\text { Environmental } \\
\text { supervision }\end{array}$ & $\begin{array}{l}\text { Establishing a clear separation of powers, orientation of supervision not only on } \\
\text { detection and termination, but also the prevention of environmental offenses. }\end{array}$ \\
\hline $\begin{array}{l}\text { Environmental } \\
\text { monitoring }\end{array}$ & $\begin{array}{l}\text { Clarification of monitoring objects and legal forms for its implementation, both at } \\
\text { the national level as a whole, and at the level of individual regions and local } \\
\text { communities; establishment of its criteria, timely review of environmental norms; } \\
\text { fixing the norm on preventing the revision of environmental standards in the } \\
\text { direction of their deterioration. }\end{array}$ \\
\hline $\begin{array}{l}\text { Environmental } \\
\text { expertise }\end{array}$ & $\begin{array}{l}\text { Specification of a specific list of objects of regional environmental expertise taking } \\
\text { into account the specific ecological, social and economic conditions of the } \\
\text { respective region. }\end{array}$ \\
\hline $\begin{array}{l}\text { Environmental } \\
\text { normalization }\end{array}$ & $\begin{array}{l}\text { Strengthening the role of the ecological norm-setting function among a number of } \\
\text { others; establishment of ecological norms depending on regional features; a } \\
\text { sufficient opportunity to adjust the established environmental standards, depending } \\
\text { on the environmental, social and economic conditions and changes. }\end{array}$ \\
\hline $\begin{array}{l}\text { Environmental } \\
\text { advice }\end{array}$ & $\begin{array}{l}\text { Introduction of the Institute of Environmental Advice as an advisory mechanism at } \\
\text { the national, regional and local levels. }\end{array}$ \\
\hline
\end{tabular}

12 Kontseptsyia эkolohycheskoi promushlennoi polytyky (kratkaia versyia) [The concept of environmental industrial policy (short version)]. Retrieved from http://docplayer.ru/26146357-Koncepciyaekologicheskoy-promyshlennoy-politiki.html [in Ukrainian]. 
Since the EU legal system is guided by the principles of promoting compliance norms and, while exercising regulatory functions, uses a permissive approach (while in Ukraine the latter are still based on command-administrative measures of influence), the convergence of legal systems requires the identification of instruments or legal provisions facilitating the transition of society and institutional structures to use more modern approaches aimed at ensuring compliance with legislative requirements, backed up by economic incentives ${ }^{13}$.

The European aspirations of our state, in particular, in the environmental sphere have been argued by the recently adopted Association Agreement between Ukraine, on the one hand, and the European Union, the European Atomic Energy Community and their member states, on the other ${ }^{14}$. The present Agreement determines that the Cooperation is aimed at preserving, protecting, improving and reproducing the quality of the environment, protecting public health, rational utilization of natural resources and encouraging measures at the international level aimed at addressing regional and global environmental problems, inter alia, in such areas:

1) climate change;

2) environmental management and similar issues, in particular education and training, access to environmental information and decision-making processes;

3) the quality of atmospheric air;

4) water quality and water management, including the marine environment;

5) waste and resources management;

6) protection of nature, in particular conservation and protection of biological and landscape diversity (eco-chain);

7) industrial pollution and industrial threats;

8) chemicals;

9) genetically modified organisms, including in agriculture;

10) noise pollution;

11) civil protection, in particular natural disasters and anthropogenic threats;

12) urban environment;

13) environmental charges ${ }^{15}$.

${ }^{13}$ Hetman, A.P., Loozo, V.I. (2016). Ymplementatsyia zakonodatelstva ob obrashchenyy s otkhodamy ES $\mathrm{v}$ pravovuiu systemu Ukraynы [Implementation of the legislation on the treatment of EU waste in the legal system of Ukraine]. Ekolohichna ta tekhnohenna bezpeka naselenykh punktiv Ukrainy: Problemy utylizatsii ta vydalennia pobutovykh ta promyslovykh vidkhodiv (ekoloho-sotsialni, tekhnichni ta pravovi problemy) Ecological and technogenic safety of settlements of Ukraine: Problems of utilization and removal of domestic and industrial waste (ecological-social, technical and legal problems): Proceedings of the International Conference (pp. 14-21). Kharkiv [in Ukrainian], p. 15.

14 Uhoda pro asotsiatsiiu mizh Ukrainoiu, z odniiei storony, ta Yevropeiskym Soiuzom, Yevropeiskym spivtovarystvom $z$ atomnoi enerhii i yikhnimy derzhavamy-chlenamy, $z$ inshoi storony: Zakon Ukrainy [Association Agreement between Ukraine, on the one hand, and the European Union, the European Atomic Energy Community and their Member States, on the other side of the law of Ukraine] (2014, September 16). Vidomosti Verkhovnoi Rady Ukrainy - Information from the Verkhovna Rada of Ukraine, 40, p. 2021 [in Ukrainian].

15 Uhoda pro partnerstvo i spivrobitnytstvo mizh Ukrainoiu i Yevropeiskymy Spivtovarystvamy ta yikh derzhavamy-chlenamy: Ratyfikovana Zakonom Ukrainy [Agreement on partnership and cooperation between Ukraine and the European Communities and their member states: ratified by the Law of Ukraine] (1994, November 10). Retrieved from http://zakon3.rada.gov.ua/laws/show/998_012 [in Ukrainian]. 
Annex XXI to Chapter 6 "Environment"16 of the above-mentioned Agreement stipulates that Ukraine undertakes to approximate its legislation into line with EU legislation within certain timeframes. This annex covers a number of spheres (see Table 3), however, somewhat narrower than the Agreement itself.

Obligations in each area include the implementation of EU Directives and the provision of certain powers to the authorities. The Association Agreement between Ukraine, on the one hand, and the European Union, the European Atomic Energy Community and their Member States, on the other hand ${ }^{17}$ provides for the implementation of a large number of acts of the European Union and the granting of certain powers to the newly created bodies, which is primarily essential progress on the road to European integration, in particular, in the environmental sphere, our state.

Implementation of the EU-Ukraine Association Agreement means, among other things, the need for introduction of European standards and norms in the field of environmental protection. Implementation of European environmental policy in Ukraine demands obligatory coordination of organizational, economic and legal aspects of governance that is crucial for its effective functioning ${ }^{18}$.

Speaking about the integration of Ukrainian legislation into pan-European, it should be noted that these procedures are sufficiently well developed and applied in practice by various state bodies of European countries. This circumstance confirms the view that integration with the EU legal system should be carried out not only at the level of legal norms, but also at the level of mechanisms for their implementation, law enforcement activities and its tools, as well as at the level of legal technic ${ }^{19}$.

16 Dodatok XXI do hlavy 6 «Navkolyshnie pryrodne seredovyshche» Uhody pro asotsiatsiiu mizh Ukrainoiu, z odniiei storony, ta Yevropeiskym Soiuzom, Yevropeiskym spivtovarystvom z atomnoi enerhii i yikhnimy derzhavamy-chlenamy, $\mathrm{z}$ inshoi storony [Annex XXI to Chapter 6 "Environment" of the Association Agreement between Ukraine, on the one hand, and the European Union, the European Atomic Energy Community and their Member States, on the other hand]. Retrieved from https://www.kmu.gov.ua/storage/app/media/ugoda-pro-asociaciyu/30_Annex.pdf [in Ukrainian].

${ }_{17}$ Uhoda pro asotsiatsiiu mizh Ukrainoiu, z odniiei storony, ta Yevropeiskym Soiuzom, Yevropeiskym spivtovarystvom $\mathrm{z}$ atomnoi enerhii i yikhnimy derzhavamy-chlenamy, z inshoi storony: Zakon Ukrainy [Association Agreement between Ukraine, on the one hand, and the European Union, the European Atomic Energy Community and their Member States, on the other side of the law of Ukraine] (2014, September 16). Vidomosti Verkhovnoi Rady Ukrainy - Information from the Verkhovna Rada of Ukraine, 40, p. 2021 [in Ukrainian].

18 Ladychenko, V., Golovko, L. (2017). Vprovadzhennia yevropeiskoi ekolohichnoi polityky v Ukraini: problemy ta perspektyvy [Implementation of European Environmental Policy in Ukraine: Problems and Prospects]. Yevropeiskyi zhurnal staloho rozvytku -European Journal of Sustainable Development (Volume 6), 3, p. 333 [in Italy].

${ }^{19}$ Gulac O., Dubchak L., Iarmolenko I., Yanchuk J. (2019) Cooperation of Ukraine and the European Union in the Ecological Sector: Directions and Prospects. European Journal of Sustainable Development. Volume 8, № 1, p. 29 [in Italy]. 
Table 3: Areas in which Ukraine has undertaken to approximate its legislation to the EU legislation regarding the authorized bodies in accordance with Annex XXX to Chapter 6 "Environment" of Section V of the Association Agreement between Ukraine, on the one hand, and the European Union, the European Atomic Energy Community and their member states, on the other

\begin{tabular}{|c|l|}
\hline № & Sphere \\
\hline 1 & environmental management and integration of environmental policy into other sectoral policies \\
\hline 2 & the quality of atmospheric air \\
\hline 3 & waste and resources management \\
\hline 4 & water quality and water management, including the marine environment \\
\hline 5 & nature protection \\
\hline 6 & industrial pollution and man-made threats \\
\hline 7 & climate change and ozone layer protection \\
\hline 8 & genetically modified organisms \\
\hline
\end{tabular}

\section{Conclusions}

Thus, the article substantiates the necessity of introducing new approaches to ensuring environmental management in Ukraine on the way to European integration. The main directions of such activity are identified and analyzed, including, through the corresponding obligations of our state, fixed by international agreements. It is proved that convergence of legal systems requires the identification of instruments or legislative provisions that promote the transition of society and institutional structures to the use of more modern approaches aimed at ensuring compliance with legislative requirements supported by economic incentives.

The European aspirations of our state, in particular, in the environmental sphere have been argued by the recently adopted Association Agreement between Ukraine, on the one hand, and the European Union, the European Atomic Energy Community and their member states, on the other.

The obligation of Ukraine regarding approximation of legislation with the EU legislation is given, concerning the authorized bodies in accordance with Annex XXX to Chapter 6 "Environment" of Section V of the Association Agreement between Ukraine, on the one hand, and the European Union, the European Atomic Energy Community and their member states, on the other, in specific directions aimed at consolidating European environmental standards.

The prospect of further research can become scientific-theoretical and applied research and development, the content of which in more detail and widely allow to analyze the necessity and effectiveness of the implementation of the new approaches to providing of environmental management in Ukraine, its directions and constituent elements in the whole diversity of environmental relations, on the way to realization of European integration aspirations of our state, given the high environmental risks and threats faced by the entire world community in environmental sphere nowadays. 


\section{References}

Andreytsev, V.I. (2016). Aktualni problemy konverhentsii ekolohichnoho zakonodavstva Ukrainy do zakonodavstva YeS [Actual Problems of Convergence of the Environmental Legislation of Ukraine to EU Legislation]. Aktualni problemy konverbentsii ekolobichnoho zakonodavstva Ukrainy do Zakonodavstva Yevropeiskoho Soinzu - Actual Problems of Convergence of the Environmental Legislation of Ukraine to EU Legislation: Proceedings of All-Ukrainian Sciences. Round Table (p. 5). Dnipro [in Ukrainian].

Averyanov, V.B. (2004). Shche raz pro zmist i spivvidnoshennia poniat «derzhavne upravlinnia» $\mathrm{i}$ "vykonavcha vlada»: problemni notatky [Once more about the content and correlation of the concepts of "state administration" and "executive power": problem notes]. Pravo Ukrainy - The law of Ukraine, 5, 113-115 [in Ukrainian].

Dodatok XXI do hlavy 6 «Navkolyshnie pryrodne seredovyshche» Uhody pro asotsiatsiiu mizh Ukrainoiu, z odniiei storony, ta Yevropeiskym Soiuzom, Yevropeiskym spivtovarystvom z atomnoi enerhii $\mathrm{i}$ yikhnimy derzhavamy-chlenamy, z inshoi storony [Annex XXI to Chapter 6 "Environment" of the Association Agreement between Ukraine, on the one hand, and the European Union, the European Atomic Energy Community and their Member States, on the other hand]. Retrieved from https://www.kmu.gov.ua/storage/app/media/ugoda-pro-asociaciyu/30 Annex.pdf [in Ukrainian].

Girenko, I.V. (2016). Pravova okhorona roslynnoho svitu Ukrainy [Legal protection of the plant world of Ukraine]. Extended abstract of Doctor's thesis. Kharkiv: Nat. lawyer acad. Ukraine to them Yaroslav the Wise [in Ukrainian].

Gulac O., Dubchak L., Iarmolenko I., Yanchuk J. (2019) Cooperation of Ukraine and the European Union in the Ecological Sector: Directions and Prospects. European Journal of Sustainable Development. Volume 8, № 1, 22-30 [in Italy].

Gulak, O.V. (2016). Do pytannia zabezpechennia ekolohichnoi bezpeky v suchasnykh sotsialnoekonomichnykh umovakh [On the issue of ensuring environmental safety in modern socioeconomic conditions]. Porivnialno-analitychne pravo - Comparative and analytical right,1, 182-185. Retrieved from http://www.pap.in.ua/1 2016/54.pdf [in Ukrainian].

Hetman, A.P., Loozo, V.I. (2016). Ymplementatsyia zakonodatelstva ob obrashchenyy s otkhodamy ES v pravovuiu systemu Ukraynd [Implementation of the legislation on the treatment of EU waste in the legal system of Ukraine]. Ekolohichna ta tekhnohenna bespeka naselenykh punktiv Ukrainy: Problemy utylizatsii ta vydalennia pobutovykh ta promyslovykh vidkhodiv (ekoloho-sotsialni, tekhnichni ta pravovi problemy) - Ecological and technogenic safety of settlements of Ukraine: Problems of utilization and removal of domestic and industrial waste (ecological-social, technical and legal problems): Proceedings of the International Conference (pp. 14-21). Kharkiv [in Ukrainian].

Kontseptsyia эkolohycheskoi promushlennoi polytyky (kratkaia versyia) [The concept of environmental industrial policy (short version)]. Retrieved from http://docplayer.ru/26146357-Koncepciyaekologicheskoy-promyshlennoy-politiki.html [in Ukrainian].

Krasnova, M.V., Balyuk, G.I., Bobkova, A.G. (2016). Problemy prava ekolobichnoi bespeky [Problems of the right to environmental safety]. Dnipro: NMU [in Ukrainian].

Ladychenko, V., Golovko, L. (2017). Vprovadzhennia yevropeiskoi ekolohichnoi polityky v Ukraini: problemy ta perspektyvy [Implementation of European Environmental Policy in Ukraine: Problems and Prospects]. Yevropeiskyi zburnal staloho rozyytku -European Journal of Sustainable Development (Volume 6), 3, 333-339 [in Italy].

Lobanov. A. A. Demenko, O. F. (2013). Yevropeiska intehratsiia Ukrainy: problemy ta perspektyvy realizatsii instytutsiinoho ta administratyvnoho potentsialu [European integration of Ukraine: problems and perspectives of institutional and administrative potential realization]. Visnyke Natsionalnoho universytetu oborony Ukrainy - Bulletin of the National Defense University of Ukraine, 5 (36), 354-357 [in Ukrainian].

Loozo, V.I. (2010). Pravovi osnovy ekolohichnoi polityky Yevropeiskoho Soiuzu [Legal bases of the European Union's environmental policy]. Extended abstract of Doctor's thesis. Kharkiv: Nat. lawyer acad. Ukraine to them Yaroslav the Wise [in Ukrainian]. 
Shevchenko, I.V. (2013). Yevrointehratsiini vyklyky dlia ekolohichnoi polityky Ukrainy [European Integration Challenges for Ukraine's Environmental Policy]. Problemy ratsionalnobo vykorystannia sotsialno-ekonomichnoho ta pryrodno-resursnoho potentsialu rehionu: Intehratsiia ta innovatsiina transformatsiia Problems of rational use of socio-economic and natural-resource potential of the region: Integration and innovation transformation, 4, 65-72 [in Ukrainian].

Svitlychny, O. P. (2011). Shchodo spivvidnoshennia poniat «derzhavne upravlinnia» i «publichna administratsiia) [The relation between the concepts of "state administration" and "public administration"]. Naukovyi visnyk Natsionalnoho universytetu bioresursiv i pryrodokorystuvannia Ukrainy: Seriia «Pravo» - Scientific Bulletin of the National University of Life and Environmental Sciences of Ukraine: Series "Law", 165-2,189-194 [in Ukrainian].

Uhoda pro asotsiatsiiu mizh Ukrainoiu, z odniiei storony, ta Yevropeiskym Soiuzom, Yevropeiskym spivtovarystvom $z$ atomnoi enerhii $i$ yikhnimy derzhavamy-chlenamy, $z$ inshoi storony: Zakon Ukrainy [Association Agreement between Ukraine, on the one hand, and the European Union, the European Atomic Energy Community and their Member States, on the other side of the law of Ukraine] (2014, September 16). Vidomosti Verkhovnoi Rady Ukrainy - Information from the Verkhouna Rada of Ukraine, 40, p. 2021 [in Ukrainian].

Uhoda pro partnerstvo i spivrobitnytstvo mizh Ukrainoiu i Yevropeiskymy Spivtovarystvamy ta yikh derzhavamy-chlenamy: Ratyfikovana Zakonom Ukrainy [Agreement on partnership and cooperation between Ukraine and the European Communities and their member states: ratified by the Law of Ukraine] (1994, November 10). Retrieved from http://zakon3.rada.gov.ua/laws/show/998 012 [in Ukrainian].

Zhochkina, I.N. (2015). Rehyonalnoe hosudarstvennoe эkolohycheskoe upravlenye: kontseptsyia sovremennoho mekhanyzma pravovoho rehulyrovanyia [Regional state environmental management: the concept of the modern mechanism of legal regulation]. Doctor's thesis. Moscow: Moscow State University named after MV Lomonosov [in Russia]. 